\begin{tabular}{|c|c|c|}
\hline Iso & $\begin{array}{c}\text { Bulletin of Pharmaceutical Sciences } \\
\text { Assiut University }\end{array}$ & \\
\hline 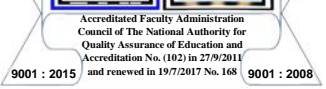 & $\begin{array}{l}\text { Website: http://bpsa.journals.ekb.eg/ } \\
\text { e-mail: bullpharm@aun.edu.eg }\end{array}$ & $\begin{array}{c}\text { BULL., PHARM. SCI. } \\
\text { Assiut univ. }\end{array}$ \\
\hline
\end{tabular}

\title{
PRODUCTION AND APPLICATION OF NATURAL FOOD PIGMENTS BY MONASCUS RUBER USING POTATO CHIPS MANUFACTURING WASTES
}

\author{
Hossam E. F. Abdel-Raheam ${ }^{1}$, Sedky H. A Hassan ${ }^{* 2}$ and Maysa M. A. Ali ${ }^{3}$ \\ ${ }^{1}$ Food sciences Department, Faculty of Agriculture, Beni-Suef Univ., Beni-Suef, Egypt \\ ${ }^{2}$ Botany and Microbiology Department, Faculty of Science, New Valley University, Egypt \\ ${ }^{3}$ Botany and Microbiology Department, Faculty of Science, Assiut University, 71516, Assiut, \\ Egypt
}

This work was established for using potato chips manufacturing wastes as a substrate for the production of food colorant pigments by Monascus ruber Went AUMC 5705, then it was utilized individually for coloring some food products (drops sweets). The effects of different environmental and nutritional factors were studied in solid state fermentation (SSF). The maximum concentrations of red, orange, and yellow pigments produced by M. ruber were 147.3, 179.6 and $221.7 \mathrm{U} / \mathrm{g}$ of dry fermented materials, respectively. The optimum conditions for pigments production were determined to be 50\%, 6.5, $3 \%$ and 15 days, for the initial moisture content, $\mathrm{pH},\left(\mathrm{NH}_{4}\right)_{2} \mathrm{SO}_{4}$, and incubation period, respectively. Moreover, the optimum inoculum size, particle size of potato chips and fermentation temperature, were determined to be $81 \times 10^{4}$ spores $/ 10 \mathrm{~g}$ dry substrate, $1.5 \mathrm{~mm}$ and $30{ }^{\circ} \mathrm{C}$ under dark condition, respectively. Then, the pigments mixture was separated into red, orange and yellow water insoluble pigments that used as coloring agents of drops sweets flavoured with fruits odours. This study revealed that potato chips wastes are an innovative raw material for pigments production by M. ruber in SSF.

\section{INTRODUCTION}

Currently, there is worldwide interest in process development of pigments production from natural sources, owing to the highest used in foods as a coloring chemical compound. These synthetic compounds have been reported to have carcinogenic and teratogenic effects. This has been one of the major reasons for the increased interest in producing pigments from biological origin like microorganisms ${ }^{1}$. Microorganisms have become an important source for pigment production due to great growth rate, low-cost culture medium, and easy extraction procedure; all these offer more benefits for microorganisms than other biological resources ${ }^{2}$. The best known of the microbial pigments are produced by Monascus group, which belongs to ascomycetes class and monascaceae family can produce many secondary metabolites such as pigments, monacolins, $\gamma$-aminobutyric acid, and dimerumic acid ${ }^{3}$.

Bio-pigments produced by Monascus are regarded the most important, because these may be used as alternates for nitrites in meat products and for synthetic colors such as erythrosine (FD and C red No3). Monascus red pigments have been used as food colorant traditionally for hundreds of years predominantly in countries like China, Thailand, Korea and Japan and are produced by using long-established solid-state fermentation method $^{4}$. It contributes to consumers favorite food colors, from orange-red to violet-red, nowadays used in food industry, and categorized into three main groups: yellow pigments (monascin, ankaflavin), orange pigments (rubropunctain, monascorubin), and red pigments (rubropunctamine, 
monoscorubramine $)^{5}$. They are synthesized as water insoluble. Aminophiles is unstable in extreme $\mathrm{pH}$ of the cytosol and multi-enzymatic polyketide synthase complex ${ }^{6}$ becoming water soluble after being in contact with present amino acids. Their aminophile characteristic makes them to be associated with cellular proteins or with the cell wall, and this makes them difficult to be extracted. Therefore, their extraction requires cell damage and extraction in organic solvent like methanol ${ }^{7 \& 8}$.

Monascus pigments can be obtained by both solid state and submerged culture. In solid state fermentation process, substrates not only supply the nutrients to the microbial culture growing but serve as harbor for the cells as well, leading to high pigment productivity. Moreover, it is cheap process uses agroindustrial residues as substrates ${ }^{9}$.

Many agricultural by-products such as corn $\mathrm{cob}^{10}$, sugarcane bagasse ${ }^{11}$, grape waste ${ }^{12}$, jackfruit seed ${ }^{13 \& 14}$, corn steep liquor ${ }^{15}$, wheat $\operatorname{bran}^{16}$, and cassava ${ }^{17}$, were successfully used for the production of Monascus pigments.

Several starch by-products produced from numerous industrial processes, signify one of the most abundant carbon resources in nature. Using these resources in the cultivation process is a promising way to reduce the cost price of produced molecules particularly like antibiotics, enzymes, etc. These resources are more attractive to provide an inexpensive industrial substrate and contribute in solving pollution problems ${ }^{18}$. Many industries all over the world use potato as raw material, potato chips manufacturing industry is one of the most productions, which depends completely on potato, during chips handling, huge quantity of residue potato fragments with unsuitable size and shape are produced. These fragments consider as a waste and take away with very low price value to use as a feed component for animals and poultry ${ }^{18}$.

In this study, some of physical and nutritional factors for optimizing the pigment production from Monascus ruber Went AUMC 5705 were studied by using of potato chips industry wastes as a substrate in solid state fermentation (SSF) conditions. The obtained natural pigments were utilized as substitutes of synthetic pigment for coloring of some food products.

\section{MATERIALS AND METHODS}

\section{Microorganism and inoculum preparation}

A culture of Monascus ruber Went AUMC 5705 that has been used in this study was provided from Assuit University Mycological center (AUMC), Assuit, Egypt. It was maintained according to the method developed by Al-Bedak et $a l^{19}$, and sub-cultured intermittently every three weeks. For inoculum preparation $M$. ruber Went AUMC 5705 was cultivated on YEPD slant agar in the dark at 30 ${ }^{\circ} \mathrm{C}$ under static conditions. To fully sporulated (6-8 days old) agar slope culture, $10 \mathrm{~mL}$ of sterile distilled water was added, and the spores were scrapped under aseptic conditions. The suspension spores were used as inoculum, described by Babitha et al. ${ }^{14}$

\section{Analysis of citrinin}

The presence of citrinin was determined by thin layer chromatography as described by Rasheva, et $a .^{20}$. Citrinin (Sigma-Aldrich, St. Louis, MO) was used as a standard.

\section{Fermentation medium:}

Wastes of potato chips manufacturing (raw pieces) were obtained from a local factory of potato chips at Assuit Governorate, Egypt. After drying at $70^{\circ} \mathrm{C}$, it was ground well to 1.0 $2.0 \mathrm{~mm}$ particle size using an electrical mill and the produced potato flour (powder) was packed in polyethylene pages until use as the basal fermentation medium.

\section{Solid-state fermentation procedures:}

Ten grams of potato powder was placed in a $250 \mathrm{~mL}$ Erlenmeyer flask and $2.0 \mathrm{~mL}$ of a nutrient salt solution $\left(\mathrm{KH}_{2} \mathrm{PO}_{4}, 2 ; \mathrm{NH}_{4} \mathrm{NO}_{3}, 5\right.$; $\mathrm{NaCl}, 1$; and $\mathrm{MgSO}_{4} \cdot 7 \mathrm{H}_{2} \mathrm{O}, 1 \mathrm{~g} / \mathrm{L}$ ) plus $1 \mathrm{~mL}$ zinc sulfate $\left(\mathrm{ZnSO}_{4} .7 \mathrm{H}_{2} \mathrm{O}, 0.128 \mathrm{M}\right)$ solution were added to each flask ${ }^{13 \& 21}$. The potato powder was soaked in water at $30^{\circ} \mathrm{C}$ for $1 \mathrm{~h}$. Flask contents were mixed, then covered with two layers of aluminum foil to prevent moisture loss and autoclaved at $121^{\circ} \mathrm{C}$ for $15 \mathrm{~min}$. After cooling to room temperature, each flask was inoculated with $1 \mathrm{ml}$ spores suspension $\left(7 \times 10^{5}\right.$ spores $/ \mathrm{mL}$ ) and incubated at $30^{\circ} \mathrm{C}$ for 10 days in the dark. Unless otherwise indicated, these conditions were maintained throughout the experiment. All experiments were conducted in 
triplicate and means \pm standard deviations were reported.

\section{Studying the optimization conditions for pigments production}

The effect of initial moisture content $(41 \%, 44 \%, 47 \%, 50 \%, 52 \%$ and $55 \%(\mathrm{~V} / \mathrm{W}))$ was adjusted by adding distilled water, incubation was for 10 days at $30^{\circ} \mathrm{C}$ in the dark. To study the effect of inoculation rate, $18 \times 10^{4}$, $27 \times 10^{4}, \quad 36 \times 10^{4}, \quad 45 \times 10^{4}, \quad 54 \times 10^{4}, 63 \times 10^{4}$, $72 \times 10^{4}, 81 \times 10^{4}$ and $90 \times 10^{4}$ (Number of Spores /10gram dry substrate(gds)) spore suspension was added under aseptic conditions after sterilization and cooling. The initial $\mathrm{pH}$ value $(4.5,5.5,6.5,7.5$ and 8.5) was achieved by adjusting the $\mathrm{pH}$ of the added sterile distilled water with $0.5 \mathrm{M} \mathrm{HCl}$ or $0.5 \mathrm{M} \mathrm{NaOH}$. To study the effect of particle sizes, potato powder of different particle sizes was used to prepare different media, viz. M1 (particles $\leq 1.0 \mathrm{~mm}$ ), M2 (particles $\leq 1.5 \mathrm{~mm}$ ) and M3 (particles $\leq 2.0$ $\mathrm{mm}$ ). To study the effect of incubation period pigments were estimated after $5,7,9,11,13$, 15,17 and 19 days of incubation.

Studying the effect of different organic and inorganic nitrogen sources were evaluated such as monosodium glutamate, peptone, yeast extract, beef extract, ammonium nitrate, ammonium sulphate, ammonium chloride, potassium nitrate and urea at $1.0 \%$ concentration of each. The optimum concentration of the selected nitrogen source which stimulates pigments production was estimated by adding it at different concentrations $(1.0,2.0,3.0,4.0$ and $5.0 \%)$ to the production medium.

\section{Pigment extraction and quantification}

At the end of incubation period, the contents of each flask were dried on aluminum foil at room temperature and ground to a fine powder using an electrical mill. A $0.5 \mathrm{~g}$ of dried powdered fermented solids was extracted with $20 \mathrm{~mL}$ of $95 \%$ ethanol in an incubator shaker for $2 \mathrm{hrs}$ at $180 \mathrm{rpm}$ in a100 mL Erlenmeyer flask. The extract was then centrifuged at $10000 \mathrm{rpm}$ for $10 \mathrm{~min}$ to remove suspended solids. The supernatant was analyzed by a spectrophotometer using a $95 \%$ ethanol blank ${ }^{22 \& 24}$. Pigments concentration was measured using a double beam spectrophotometer (UViline 9400-SCHOTT Instruments, EU) at 400, 470 and $500 \mathrm{~nm}$ for yellow, orange and red pigments, respectively, taking into consideration the dilution factor of the sample ${ }^{22 \& 25}$. The results were expressed as absorbance unit (AU) per gram of dried solids $^{26}$. The pigment absorbance was calculated using the equation:

The absorbance unit of pigments

$$
\left(\mathrm{AU} g^{-1}\right)=A b s \times \frac{20}{0.5} \times d f
$$

\section{Separation of pigments for application in the preparation of drops sweets products:}

The mixture of red, orange and yellow pigments was separated and purified individually from the dried fermented potato powder as described by Abdel-Raheam ${ }^{27}$, to form separate water insoluble pigments ready to use as food colorants as shown in Figure (1).

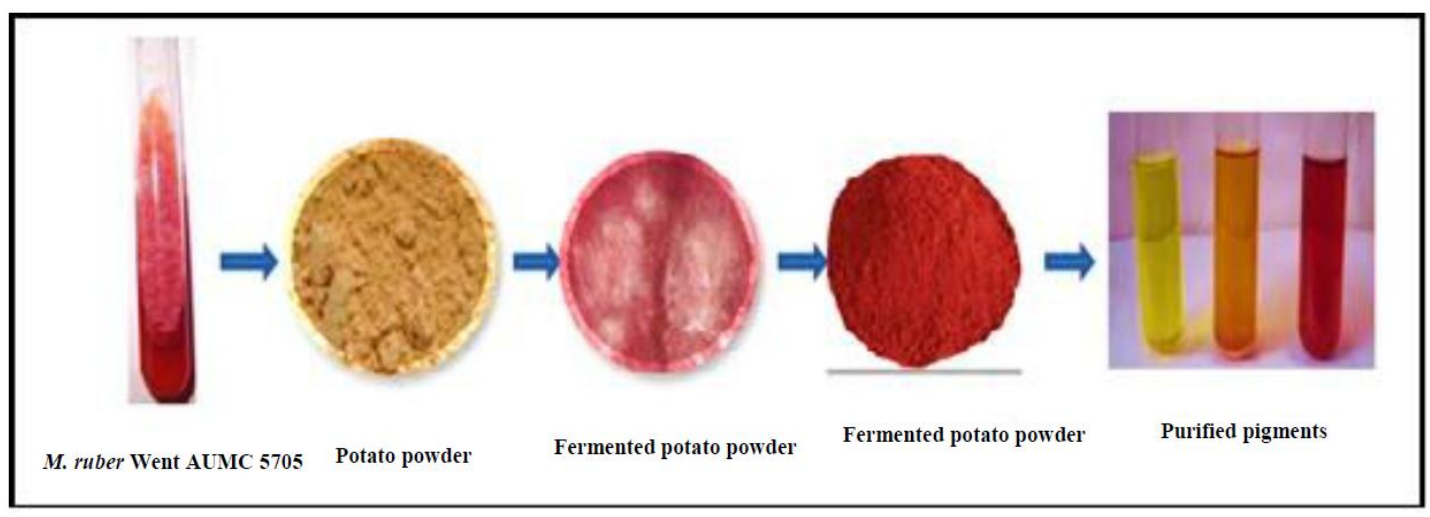

Fig. 1: Separation of red, orange and yellow pigments individually from dried fermented potato powder culture 


\section{Processing of drops sweets}

Drops sweets were prepared by mixing sucrose $(242.4 \mathrm{~g} / \mathrm{l})$, corn syrup (129.5 g/l), water $(126.6 \mathrm{~g} / \mathrm{l})$ and citric acid $(0.75 \mathrm{~g} / \mathrm{l})$ then heated to $157{ }^{\circ} \mathrm{C}$. Quickly, it was cooled to $110^{\circ} \mathrm{C}$. Flavouring agent $(1.05 \mathrm{~g} / \mathrm{l})$ and separated Monascus ruber pigments (which separated from dried solid-state culture) were added individually to produce red, orange and yellow drops sweets ${ }^{27}$. These contents should be mixed very well and put in forming blocks until it became solid, then packed in special foil.

\section{Sensory evaluation}

Sensory evaluation was carried out by ten panelists. The panelists were asked to evaluate taste, colour, texture, odor and over all acceptability for prepared drops sweets according to the method described by Reitmeier and Nonnecke ${ }^{28}$.

\section{Statistical analysis}

All the obtained data for the experiment were subjected to the statistical analysis of CRD (complete randomized design) according to Gomez and Gomez ${ }^{29}$. The significant means of any trait studied were compared using LSD at $5 \%$ probability level according to Waller and Duncan $^{30}$

\section{RESULTS AND DISCUSSION}

Monascus pigments know as traditional pigments with highly safety, richly nutrition and wide application have been widely used in Southeast Asia for thousands of years. Moreover, the application of Monascus pigments have been extended to modern food industry, for example, meat products, fish sauce and so $\mathrm{on}^{31}$. These pigments characterized by their wide applications, the flexibility of production and down streaming processes. In addition, it enhances the flavor of the food and acts a food preservative.

\section{Optimization of pigments production conditions}

\section{Effect of initial moisture content}

Among all 6 different moisture content tested for pigment production (Figure, 2). The results showed that $M$. ruber Went AUMC 5705 produced maximum amount of yellow, orange, and red pigments were $10.82,7.56$ and $9.14 \mathrm{AU} / \mathrm{g}$, respectively at $50 \%$ moisture content of the substrate (Figure 2). Our results were consistent with Raimbault ${ }^{32}$, who reported that the optimal initial moisture content for pigments production tends to be in the range of 40 to $70 \%$. Yongsmith et al. $^{33}$, noticed that the moisture content of substrate is important in fungal growth, enzyme activity, and metabolites production in SSF this was concerned to effective utilization of sugars in the substrate.

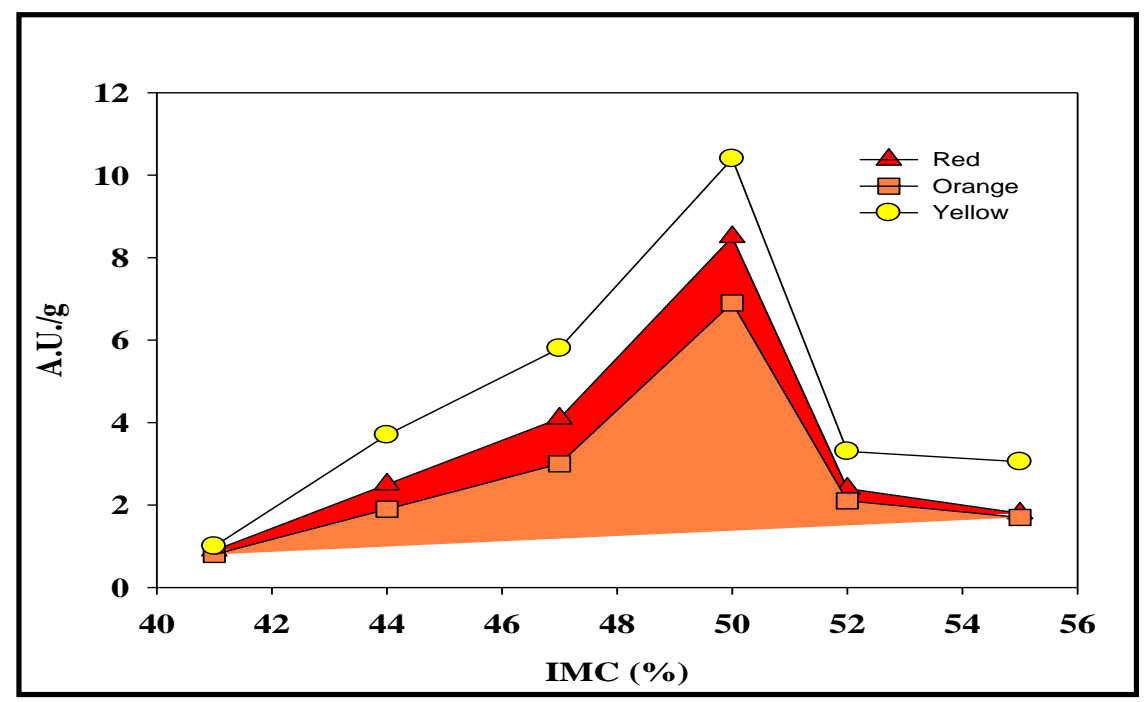

Fig. 2: Effect of initial moisture content (IMC) on pigments production by $M$. ruber Went AUMC 5705 grown on potato wastes using solid state fermentation. 


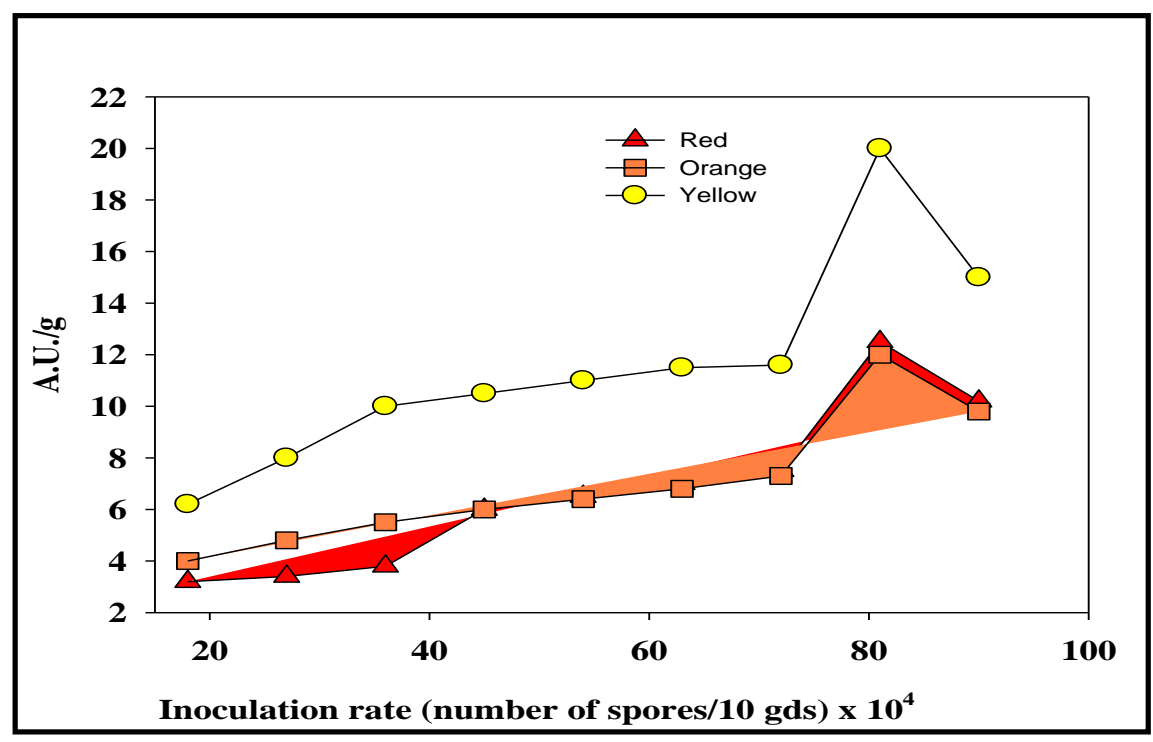

Figu. 3: Effect of inoculum sizes on pigments production by $M$. ruber grown on potato wastes using solid state fermentation.

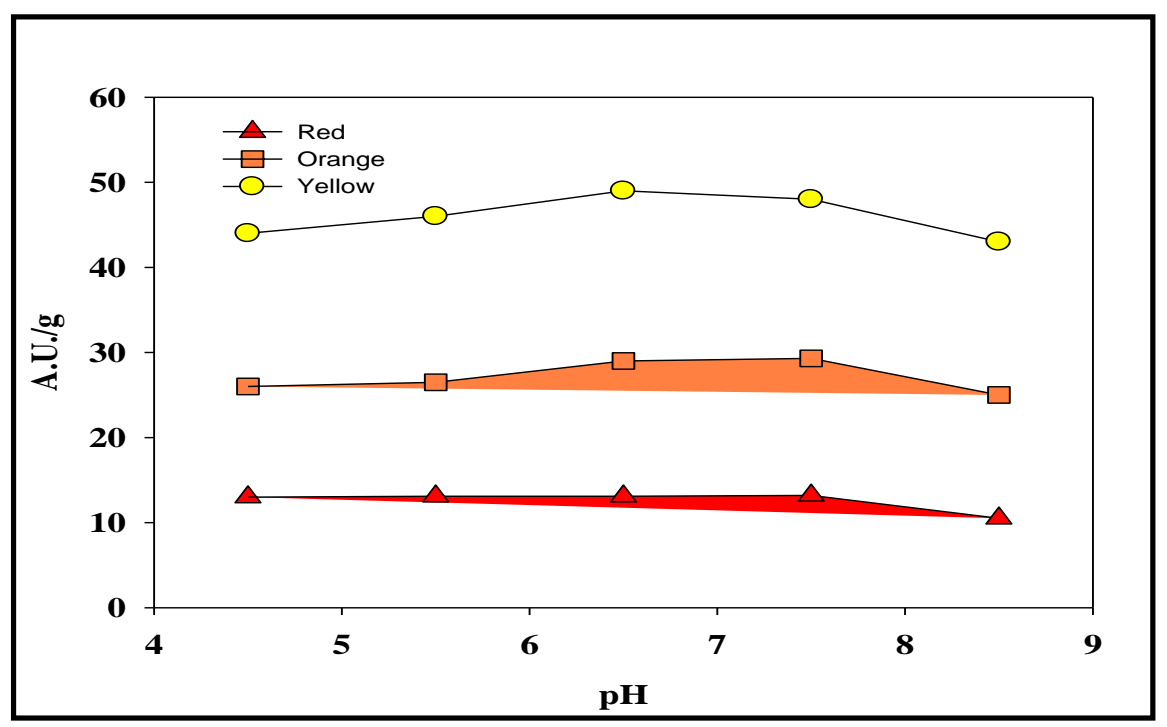

Fig. 4: Effect of Initial $\mathrm{pH}$ on pigments production by $M$. ruber grown on potato wastes using solid state fermentation.

\section{Effect of inoculation size}

Figure (3) shows a peak increasing in yield of yellow pigment (20.50 AU/gds), followed by orange pigment (14.16 AU/gds), and red pigment $(15.80 \mathrm{AU} / \mathrm{gds})$ at inoculum size $81 \times 10^{4}$ (spores/10 gds). The current results are widely varied from that described by other researchers ${ }^{10 \& 14 \& 34-35}$, they reported that, the optimal inoculum size for pigments production was $4 \mathrm{ml}$ of spores $\left(6 \times 10^{5}\right.$ spores $\left./ \mathrm{ml}\right) / \mathrm{g}$ of initial dried substrate (gds). Babitha, et al. ${ }^{14}$, demonstrate that little inoculum caused insufficient biomass and smaller amounts of the product, whereas too much inoculum produced excessive biomass and provided the essential nutrients for pigment formation.

\section{Effect of initial pH}

The best yield of pigments was obtained at pH 6.5 (15.12, 14.16, and 20.50 AU/g for red, orange, and yellow pigments separately). Production of yellow and orange pigments tends to fall in both acidic ( $\mathrm{pH} 4.5-5.5)$ and alkaline ( $\mathrm{pH}$ 7.5-8.5) values. Chen and Johns ${ }^{36}$, Lee et $a l .{ }^{37}$ and Joshi et $a l .^{38}$ revealed that the suitable $\mathrm{pH}$ range for growth and production of Monascus pigments was 5.5-6.5 (figure, 4). This result was near to that of Babitha, et al. ${ }^{14}$, who described maximum pigments production by $M$. purpureus at $\mathrm{pH} 4.5$ to 7.5 , while using 
jack fruit seed as substrate in solid state fermentation.

\section{Effect of potato particle size}

it has been noticed that $1.5 \mathrm{~mm}$ size of potato particles is the best size for producing yellow, orange and red pigments by $M$. ruber (Figure, 5). In the contrary of the present results, Babitha et $a l .{ }^{13}$, found that $M$. purpureus LPB 97 produced the maximum pigments level on media consists of Jack fruit seeds with particles size between 0.4 and 0.6 mm. Usually, smaller particles of substrate offer a larger surface area for microbial dose, and thus it should be considered as a good factor. However, too small particles could result in substrate accumulation, which may affect in aeration which leads to poor microbial growth. At the same time, larger particles cause better aeration effectiveness but provide limited surface for microbial attack. Therefore, it may be necessary to provide suitable particle size $e^{34}$.

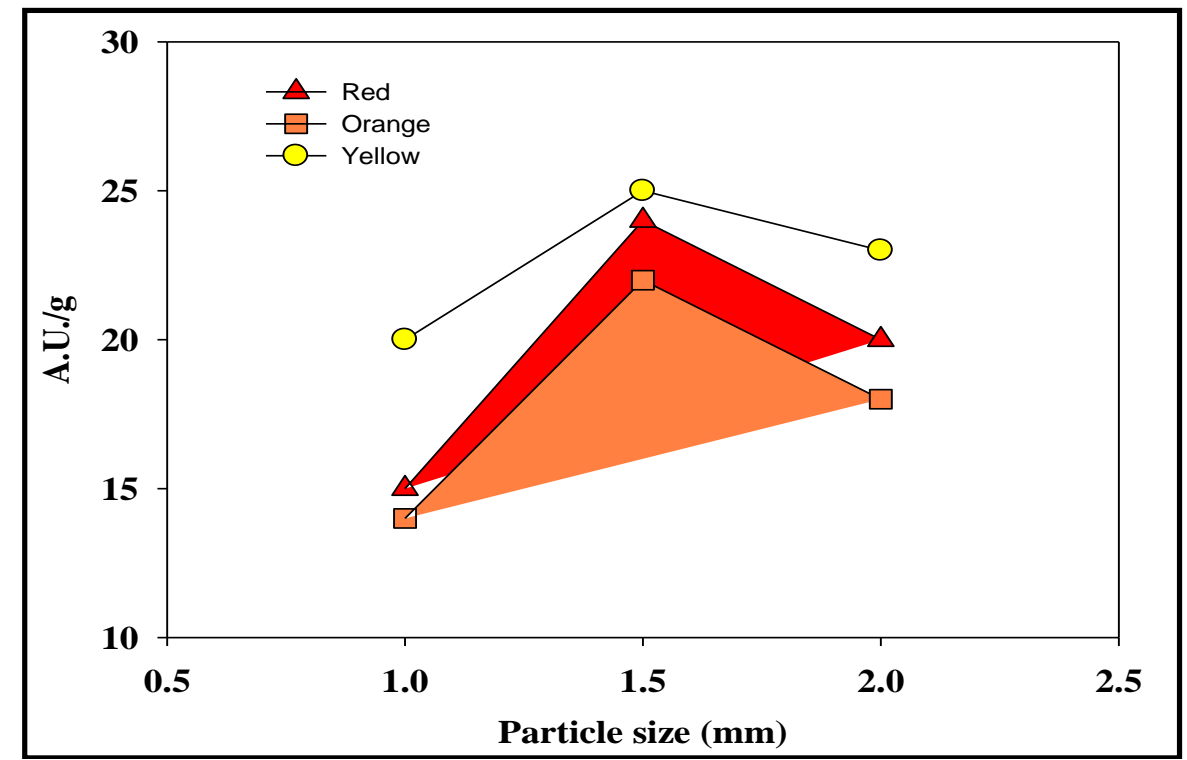

Fig. 5: Effect of particle sizes on pigments production by M. ruber grown on potato wastes using solid state fermentation.

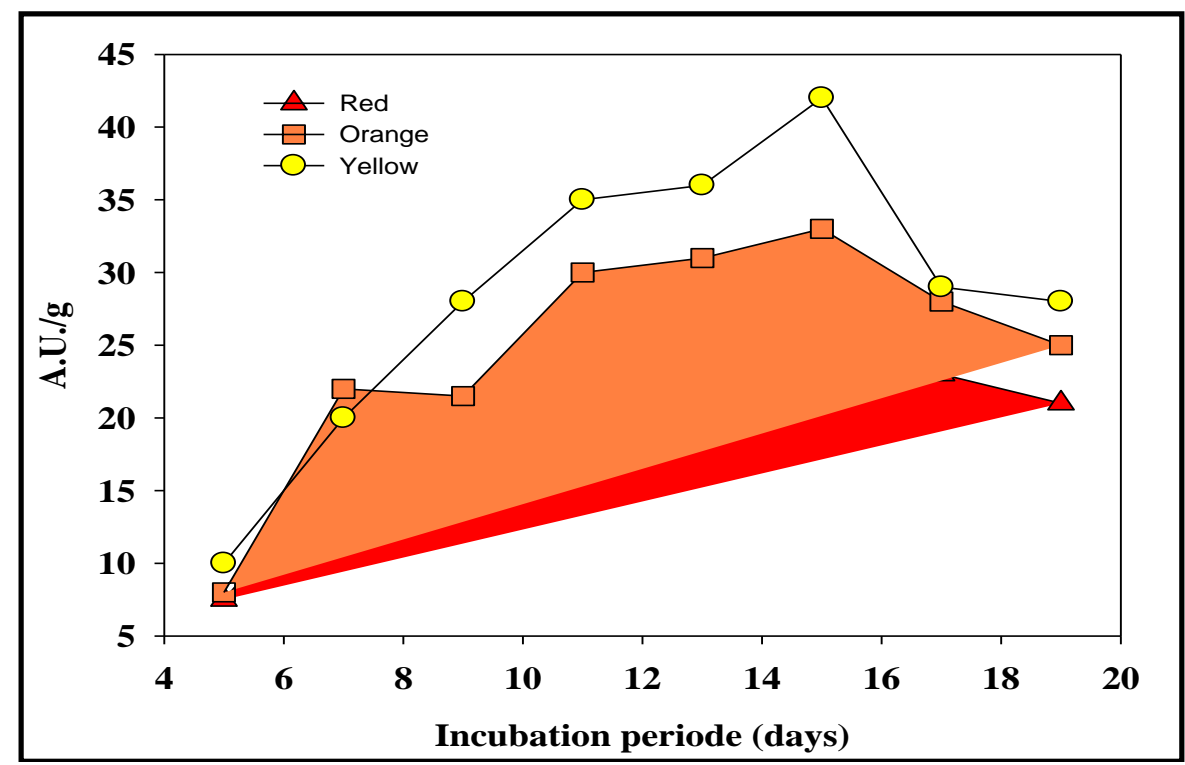

Fig. 6: Effect of incubation period on pigments production by $M$. ruber grown on potato wastes using solid state fermentation. 


\section{Effect of incubation period}

The concentration of pigments produced were increased gradually with increasing the incubation time (Figure, 6). Maximum yellow, orange and red pigments production was obtained after 15 days (43.48 AU/g, 34.94 $\mathrm{AU} / \mathrm{g}$ and $31.24 \mathrm{AU} / \mathrm{g}$, respectively). Results are in harmony with Emon et al. ${ }^{39}$, who noticed that the maximum concentration of pigments was obtained after 2 weeks of incubation by $M$. purpureus CMU001, grown on Korkor 6 white glutinous rice as substrate in solid state fermentation. The current results are rather differed from this described by Velmurugan, et $a l .{ }^{10}$, they reported that the maximum pigments production was achieved by $M$. purpureus KACC 42430 within 7 days by using corn cob as substrate in solid state fermentation.

\section{Effect of nitrogen source}

Nine sources of organic and inorganic nitrogen were separately studied at concentration of $1 \%$ to fermentation media. From the spectral analysis it has been observed that only ammonium sulphate showed a peak effect which duplicated the producing amount of yellow, orange, and red pigments to reach 130.4, 93.72 and $80.36 \mathrm{AU} / \mathrm{g}$, respectively when compared with control (Figure, 7). To estimate the optimum concentration of ammonium sulphate that was the best nitrogen source. We tested different concentrations of it $(1,2,3,4$ and $5 \%)$. Data illustrated in figure (8) indicated that $3 \%$ ammonium sulphate proved to be the optimum concentration for maximum pigments production. The obtained color intensity of red, orange, and yellow pigments increased from 80.36, 93.72 and $130.40 \mathrm{AU} / \mathrm{g}$ to $147.30,179.6$ and $221.7 \mathrm{AU} / \mathrm{g}$, respectively by increasing ammonium sulphate concentration from 1.0 to $3.0 \%$. The higher concentrations (4 and $5 \%$ ) of ammonium sulphate haven't the same stimulatory effect. Vidyalakshmi et $a .^{40}$; Rashmi and Padmavathi ${ }^{41}$, reported that by using rice as production medium, addition of mono sodium glutamate (MSG) was the best nitrogen source, and the optimum concentration was $5 \%$.

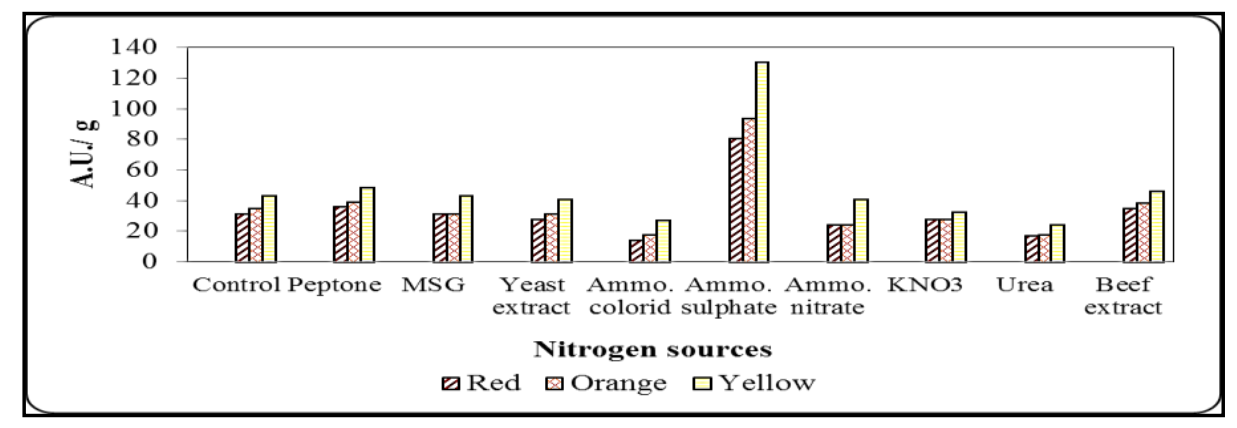

Fig. 7: Effect of nitrogen sources on pigments production by $M$. ruber grown on potato wastes using solid state fermentation

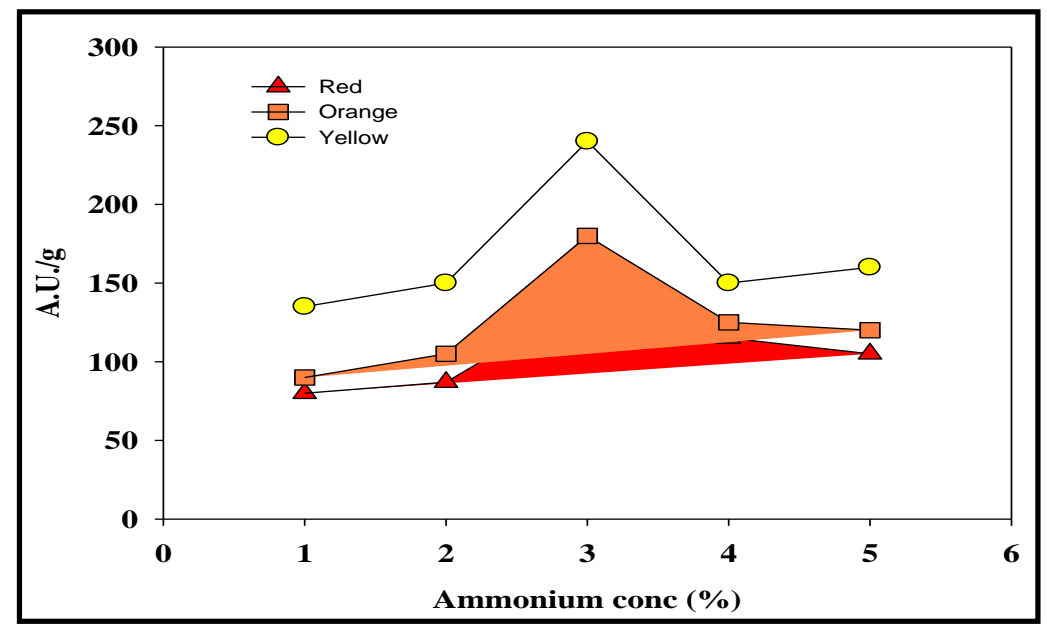

Fig. 8: Effect of different concentrations of ammonium sulphate on pigments production by M. ruber grown on potato wastes using solid state fermentation. 
Qualitative analysis of citrinin using thinlayer chromatography (TLC):

TLC analysis showed that no citrinin was detected in solid state culture extract. Hence the Monascus ruber used in this study was found to be safe for food use.

\section{Sensory evaluations of some food products}

Produced pigments were extracted and separated from SSF Monascus ruber culture after optimization and utilized as colorants additives for the development of food products as described by Abdel-Raheam ${ }^{27}$. The food products namely red, orange, and yellow drops sweets were developed by adding the separated Monascus pigments individually. In the current study, Monascus ruber pigments directly mixed with the food products during their preparation to impart yellow, orange, and red pigments individually to these products (Figure 9) and improving the aesthetic value. The food products prepared using Monascus pigments as colorants were sensory evaluated for taste, color, texture, odor and over all acceptability by ten panelists.

Data in Table (1) shows the average sensory analysis scorecard and all scores for the separated Monascus ruber pigments as natural colors for the butterscotch flavored drops sweets. The overall average score for the red, orange, and yellow drops sweets samples were 45.9, 45.3 and 46.3, respectively. In general, all prepared products were recorded highly scores in all sensory evaluated tested parameters as shown in table (1).

The range score for taste, color, texture, odor and over all acceptability were between 8.6 to 9.8 scored which describes as 'like extremely' for all studied food samples as described by Wang and Zhao ${ }^{42}$. The result shows that using of Monascus ruber pigments for coloring tested food products has proved to be excellent. The pigment dispersed evenly in the food samples which giving an attractive appearance. Besides the application of the natural pigment encourages consumers, health protection $^{43}$.

These results were near to those reported by Blanc et ll $^{44}$, who noticed that food samples show more powerful and stable red colour and improved organoleptic characteristics when Monascus purpureus pigment was used. Usually, red rice, red wine, sausages, fish sauces, meat products and soybean curd were prepared with these pigments. Vidyalakshmi et $a l{ }^{40}$, reported that Monascus fermented rice (MFR) when used as colorants in the preparation of food product (kesari), it displayed very good color and appearance. They also calculated the incorporation of MFR for colouring flavored milk, which showed an attractive color and appearance with better acceptability. Also, these results agree with the reports of other reserachers ${ }^{45-48}$.

Table (1): Mean sensory scores of red, orange, and yellow drops sweets samples colored with Monascus ruber pigments

\begin{tabular}{|c|c||c|c|c|c||c||c||}
\hline No. & $\begin{array}{c}\text { Name of } \\
\text { product }\end{array}$ & $\begin{array}{c}\text { Taste } \\
(10)\end{array}$ & $\begin{array}{c}\text { Colour } \\
(10)\end{array}$ & $\begin{array}{c}\text { Odor } \\
(10)\end{array}$ & $\begin{array}{c}\text { Texture } \\
(10)\end{array}$ & $\begin{array}{c}\text { Overall } \\
\text { Acceptability } \\
(10)\end{array}$ & $\begin{array}{c}\text { Total score } \\
(50)\end{array}$ \\
\hline \hline 1 & $\begin{array}{c}\text { Red drops } \\
\text { sweet }\end{array}$ & $9.0^{\mathrm{a}}$ & $9.2^{\mathrm{a}}$ & $8.8^{\mathrm{a}}$ & $9.8^{\mathrm{a}}$ & $9.1^{\mathrm{a}}$ & $45.9^{\mathrm{a}}$ \\
\hline \hline 2 & $\begin{array}{c}\text { Orange drops } \\
\text { sweet }\end{array}$ & $8.6^{\mathrm{a}}$ & $9.4^{\mathrm{a}}$ & $9.0^{\mathrm{a}}$ & $9.0^{\mathrm{a}}$ & $9.3^{\mathrm{a}}$ & $45.3^{\mathrm{a}}$ \\
\hline \hline 3 & $\begin{array}{c}\text { Yellow drops } \\
\text { sweet }\end{array}$ & $9.5^{\mathrm{a}}$ & $8.9^{\mathrm{a}}$ & $9.1^{\mathrm{a}}$ & $9.3^{\mathrm{a}}$ & $9.5^{\mathrm{a}}$ & $46.3^{\mathrm{a}}$ \\
\hline \hline & L.S.D & $\mathrm{NS}$ & $\mathrm{NS}$ & $\mathrm{NS}$ & $\mathrm{NS}$ & $\mathrm{NS}$ & $\mathrm{NS}$ \\
\hline
\end{tabular}

Means with the same letters in the same column are not significant different at $<0.05$ level of probability. NS = non-significant. 


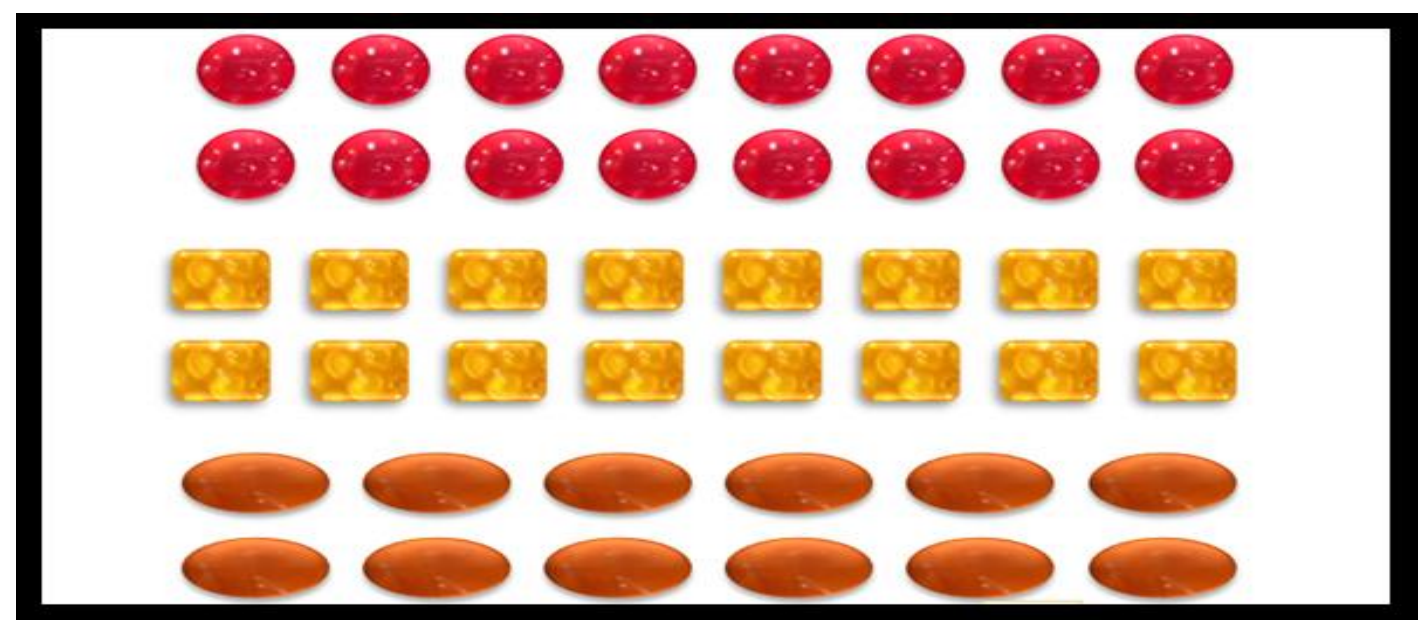

Fig. 9: The red, yellow, and orange drops sweets prepared by separated M. ruber pigments

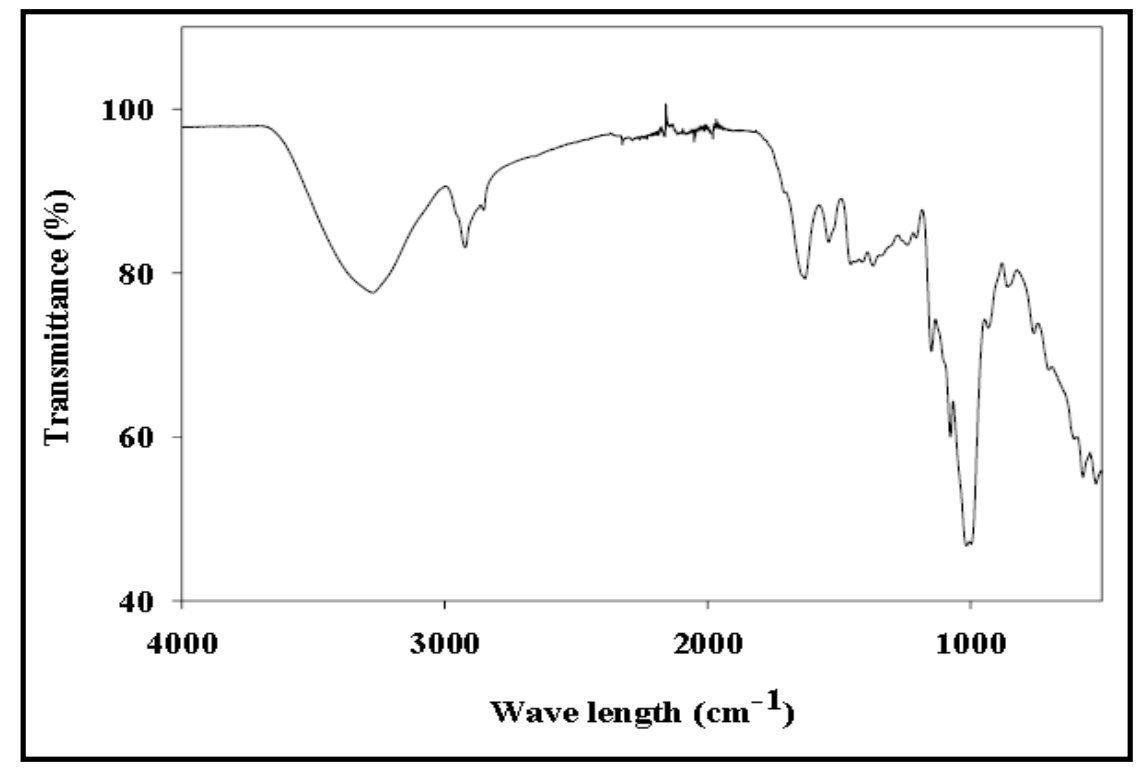

Fig. 10: FT-IR spectrum of $M$. ruber pigments

\section{FTIR of M. ruber pigments}

Fourier transform infrared (FTIR) for the $M$. ruber pigments was characterized by FTIR spectroscopy according to Hassan et al. ${ }^{49}$. The spectrum was illustrated in Figure (10). The absorption bands characterizing hydroxyl $\mathrm{OH}^{-}$was detected at $3200-3600 \mathrm{~cm}^{-1}$, alkyl chains and $\mathrm{CHO}$ detected in the range 2921$2851 \mathrm{~cm}^{-1}, \mathrm{C}=\mathrm{O}$ at $1648-1546 \mathrm{~cm}^{-1}$, the band located at $1100-1200 \mathrm{~cm}^{-1}$ may indicate to phosphate group $\mathrm{P}=\mathrm{O}$, the spectrum 1210-1320 $\mathrm{cm}^{-1}$ strong intensity was attributed to the C-O link of the acidic groups. The bands in the range between 1034 and $1075 \mathrm{~cm}^{-1}$ may be indicate to organic phosphate $\mathrm{C}-\mathrm{PO}_{2}^{-3}$ groups affinity.

\section{Conclusion}

Overall, the best concentration of red, orange and yellow pigments were 147.3, 179.6 and $221.7 \mathrm{AU} / \mathrm{g}$ dry fermented material, respectively. The results revealed that potato chips wastes are an innovative raw material for pigments production by $M$. ruber Went AUMC 5705 in SSF. In addition, it is economic and environment friendly. In this study, optimization of nutritional and environmental conditions had a significant effect on the pigment production which raised $M$. ruber pigments concentration to $19.5,22.8$ and 15.1 times more than basal medium for yellow, orange, and red, respectively. The pigment was applied as coloring agent for conventional sugar confectionary (red, orange, and yellow drops sweets) it found to be greatly acceptable. 


\section{Acknowledgment}

The authors are grateful to the Department of Food Science, Faculty of Agriculture, BeniSuef University, Egypt. Also, Department of Botany and Microbiology, Faculty of Science, Assuit University, Egypt. For extending the laboratory facilities for completion of this work.

\section{REFERENCES}

1. P. Unagul, P. Wongsa, P. Kittakoop, S. Intamas, P. Srikiti-Kulchai, and M. Tanticharoen "Production of red pigments by the insect pathogenic fungus Cordyceps unilateralis BCC 1869", Ind Microbiol Biotechnol, 32, 135-140, (2005).

2. P. L. Juzlova, L. Martinkova, J. Lozinski, and F. Machek "Ethanol as substrate for pigment production by the fungus Monascus purpureus", Enz Microbiol Technol, 16, 231-235 (1994).

3. M. J. Cheng, M. D. Wu, I. S. Chen, M. Tseng, and G.F. Yuan "Chemical constituents from the fungus Monascus purpureus and their antifungal activity", Phytochem Lett, 4, 372-376, (2011).

4. A. Makhmur, and P. P. Bibhu, "Optimization of red pigment production by Monascus purpureus MTCC 369 under solid-state fermentation using response surface methodology", Songklanakarin J Sci Technol, 36 (4), 439-444, (2014).

5. T. H. Wang, T. F. Lin "Monascus rice products", Adv Food and Nutr Res,53, 123-59, (2007).

6. B. Balakrishnan, C. C. Chen, T.M. Pan, and H. J. Kwon, "Mpp7 controls regioselective Knoevenagel condensation during the biosynthesis of Monascus azaphilone pigments", Tetrahedron Lett, 55, 1640-1643 (2014).

7. S. H. Patricia, F. B. O. Sandra, Beatriz V.K. "Concentration determination of extracellular and intracellular red pigments produced by Monascus sp", Braz Arch Biol Technol. 48, 43-49, (2005)

8. Q. Liu, N. Xie, Y. He, L. Wang, Y. Shao, H. Zhao, and F. Chen, "MpigE, a gene involved in pigment biosynthesis in Monascus ruber M7", Appl Microbiol Biotechnol, 98, 285-296 (2014).

9. S.S. Teng, and W. Feldheim, "Anka and anka pigment production", J Indus Microbiol Biotechnol, 26, 280-282, (2001).

10. P. Velmurugan, H. Hur, V. Balachandar, K. S. Kamala, K. J. Lee, S. M. Lee, J.C Chae, P. Shea, and B. T. Oh, "Monascus pigment production by solid-state fermentation with corn cob substrate", $\boldsymbol{J}$ Biosci Bioeng, 112:6, 590-594 (2011).

11. S. T. Silveira, D. J. Daroit, V. Sant'Anna, and A. Brandelli, "Stability modeling of red pigments produced by Monascus purpureus in submerged cultivations with sugarcane bagasse", Food Bioproc Technol. (2011).

12. S.T. Silveira, D.J. Daroit, and A. Brandelli, "Pigment production by Monascus purpureus in grape waste using factorial design. LWT", Food Sci. Technol, 41, 170-174, (2008).

13. S. Babitha, C.R. Soccol, and A. Pandey, "Jackfruit Seed - a novel substrate for the production of Monascus pigments through solid-state fermentation", Food Technol Biotechnol, 44, 465-471, (2006).

14. S. Babitha, C.R. Soccol, and A. Pandey, "Solid-state fermentation for the production of Monascus pigments from jackfruit seed", Bioresour Technol, 98, 1554-1560. (2007).

15. P.S. Hamano, and B.V. Kilikian, "Production of red pigments by Monascus ruber in culture media containing corn steep liquor", Braz J Chem Eng, 23, 443449. (2006).

16. R.M. Dominguez-Espinosa, and C. Webb, "Submerged fermentation in wheat substrates for production of Monascus pigments", World J Microbiol Biotechnol, 19, 329-336, (2003).

17. B. Yongsmith, W. Tabloka, W. Yongmanitchai, and R. Bavavoda, "Culture conditions for yellow pigment formation by Monascus sp. KB 10 grown 
on cassava medium", World J Microbiol

Biotechnol, 9, 85-90 (1993).

18. H. E. F. Abdel-Raheam, M. K. Farag, W. S. Ragab, E. A. Ramadan, and N.M. Mahmoud, "Potato Manufacturing Wastes - A Novel Substrate for the Production of Natural Pigments from Monascus purpureus", Assiut J of Agric Sci, 47 (2), 13-23 (2016).

19. O. A. Al-Bedak, R. M. Sayed, and S. H. A. Hassan, "A new low-cost method for longterm preservation of filamentous fungi." Biocatal Agric Biotechnol, 22, 101417. (2019).

20. T. Rasheva, T. Nedeva, J. - N. Hallet, and A. Kujumdzieva, "Chareterization of a non-pigment producing Monascus purpureus mutant strain", Ant van Leewenhoek, 83, 333-340 (2003).

21. P. Nimnoi, and S. Lumyong, "Improving solid-state fermentation of Monascus purpureus on agricultural products for pigment production", Food Bioproc Technol, 4, 1384-1390, (2009).

22. S.W. Chiu, and Y.K. Poon,"Submerged production of Monascus pigments", Mycologia, 85, 214-218, (1993).

23. M.R. Johns, and D.M. Stuart, "Production of pigments by Monascus purpureus in solid culture", J Ind Microbiol, 8, 23-28, (1991)

24. T. F. Lin, K. Yalcushijin, G. H. Buchi, and A. L. Demain, "Formation of watersoluble Monascus red pigments by biological and semi-synthetic processes", $\boldsymbol{J}$ Ind Microbiol, 9, 173-179, (1992)

25. J. C. D. Carvalho, A. Pandey, S. Babitha, and C.R. Soccol, "Production of Monascus biopigments: An overview", Agro Food Ind Hi-Tech, 14, 37-42, (2003).

26. C.F. Lin, and H. Iizuka, "Production of extracellular pigment by a mutant of Monascus kaoliang sp. Nov", Appl Microbiol Biotechnol, 43, 671-676, (1982).

27. H. E. F. Abdel-Raheam, (2016). Production and evaluation of some natural food pigments from Monascus purpureus fungus. Ph.D. Thesis, Faculty of Agriculture, Assiut University, Egypt.

28. C.A. Reitmeier, and G.R. Nonnecke, "Objective and sensory evaluation of fresh fruit of day neutral strawberry cultivars", J. Hor. Sci. 26, 843-845 (1991).

29. K. A. Gomez, and A. A. Gomez, Statistical Procedures for Agriculture Research. A Wiley-Inter Sci. Publication, John Wiley and Sons, Inc. New York, USA. (1984).

30. R. A. Waller, and D. B. Duncan, "A bays rule for the symmetric multiple comparison problem", Amer State. Assoc. J. Dec., 1458-1503, (1969).

31. Y. Lin, T. Wang, and M. Lee, "Biologically active components and nutraceuticals in the Monascus-fermented rice: a review", Appl Microbiol Biotechnol, 77, 965-973 (2008).

32. M. Raimbault, "General and microbiological aspects of solid-state fermentation", Electron J Biotechnol, 1, 174-188 (1998).

33. B. Yongsmith, V. Kitprechavanich, L. Chitrandon, C. Chaisrisook, and N. Budda, "Color mutants of Monascus sp. KB9 and their comparative glucoamylase on rice solid culture", J Mol Catal B: Enzym., 10, 263-272 (2000).

34. A. Pandey, C. R. Soccol, and D. Mitchell "New developments in solid-state fermentation: I -Bioprocess and products", Process Biochem, 35, 1153-1169. (2000).

35. D. Chakradhar, S. Javeed, and A. P. Sattur, "Studies on the production of nigerloxin using agro-industrial residues by solidstate fermentation", J Ind Microbiol Biotechnol, 36, 1179-1187, (2009).

36. M. H. Chen, and M.R. Johns, "Effect of $\mathrm{pH}$ and nitrogen source on pigment production by Monascus purpureus ", Appl Microbiol Biotechnol, 40,132-138, (1993).

37. B. K. Lee, H.Y. Piao, and W.J. Chung, "Production of red pigments by Monascus purpureus in solid-stated culture", Biotechnol Bioprocess Eng,7, 21-25, (2002). 
38. V. K. Joshi, D. Attri, A. Bala, and S. Bhushan, S. Microbial pigments. Indian J Biotechnol 2, 362-369, (2003).

39. C. Emon, C. Griangsak, W. Suganya, and L. Saisamorn, "Preparation of red yeast rice using various thai glutinous rice and Monascus purpureus CMU001 isolated from commercial Chinese red yeast rice sample", Kmitl Sci Tech J, 7, 28-30. (2007).

40. R. Vidyalakshmi, R. Paranthaman, S. Murugesh, and K. Singaravadivel, "Stimulation of Monascus Pigments by Intervention of Different Nitrogen Sources", Glob J Biotechnol \& Biochem, 4, 25-28, (2009).

41. D. Rashmi, and T. Padmavathi, "Monascus purpureus: A potential source for natural pigment production", J Microbiol Biotech Res, 1, 164-174, (2011).

42. E. X. Wang, and J. Zhao, "Application of sensory evaluation in meats", Meat Res, 9, 78-82. (2008), (In Chinese).

43. M. Baranová, P. Mal'a, O. Burdová, M. Hadbavný, and G. Sabolová, "Effect of natural pigment of Monascus purpureus on the organoleptic characters of processed cheeses", Bull Vet Ins Pulawy, 48, 63-68. (2004).

44. P. J. Blanc, J. P. Laussac, J. Le Bars, P. Le Bars, Bars Le, M.O. Loret, A. Pareilleux, D. Prome, J.C. Prome, A.L. Santerre, and G. Goma, G, "Characterization of monascidin A from Monascus as citrinin", Int J Food Microbiol, 27, 201-213 (1995).
45. H. F. Mamucod, and E.I. Dizon, "Potential of biopigments from Monascus purpureus Went as natural food colorant for Philippine native sausage (Longganisa)". Int P Chem Bio Environ Eng, 71,72-76. (2014).

46. P. Pattanagul, R. Pinthong, and A. Phianmongkhol, "Review of Angkak Production (Monascus purpureus)", Chiang Mai J. Sci., 34 (3), 319-328, (2007).

47. K. Kraboun, N. Jittrepotch, T. Kongbankerd, and K. Rojsuntornkitti, K, "Effect of Monascus pigments from broken rice on inhibition of rancidity in Chinese sausage. Proceedings of $47^{\text {th }}$ Kasetsart University Annual Conference: Agro-Industry, Kasetsart University, Bangkok, Thailand, 365-373, (2009).

48. E. L. El-Kholie, M. K. El Shaer, M. A. T. Abdelreheem, and M. A. Gharib, "Detailed evaluation of a newly attained fungal pigments from Monascus purpureus in meat burgers", Int J Food Sci Nutr, 63 (7), 860-865, (2012).

49. S. H. A. Hassan, M. Koutb, N. A. Nafady, and E. A. Hassan, "Potentiality of Neopestalotiopsis clavispora ASU1 in biosorption of cadmium and zinc", Chemosphere, 202, 750-756. (2018). 


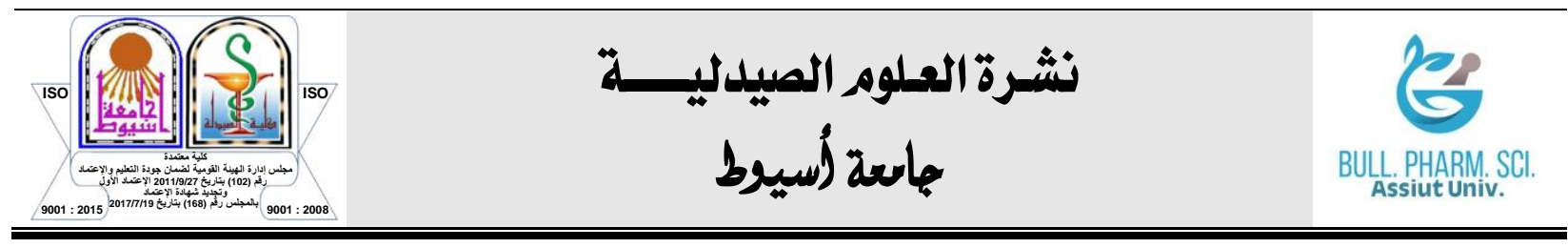

\title{
Monascus ruber إنتاج واستخدام أصباغ الطعام الطبيعية التي تنتجها فطرة باستخدام مخلفات تصنيع رقائق البطاطس
}

\author{
حسام الدين فرغلى عبدالرحيم' - صدقي حسن علي حسن - - مايسة محمد أحمد عليَ \\ ' قسم الصناعات الغذائية ، كلية الزراعه ، جامعة بني سويف ، بني سويف ، مصر

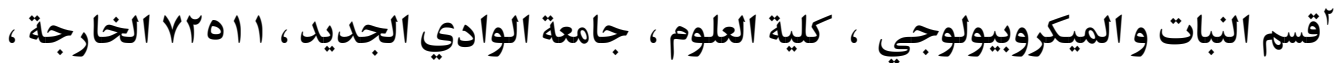 \\ الوادي الجديد ، مصر \\ "قسم النبات و الميكروبيولوجي ، كلية العلوم ، جامعة اسيوط 1017 101 ، اسيوط ، مصر
}

الغرض الأساسي من هذا البحث هو استخدام مخلفات تصنيع رقائق البطاطس كركيزة لإنتاج

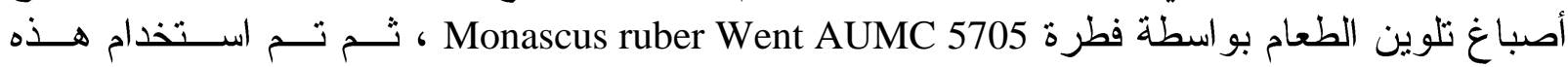
الصبغات بشكل فردي لتلوين بعض المنتجات الغذائية (الحلويات). تمت دراسة تأثثير ات العو امل البيئية

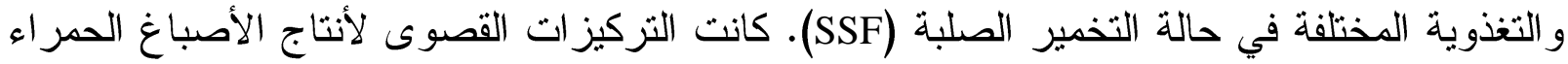

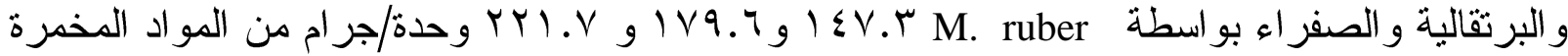

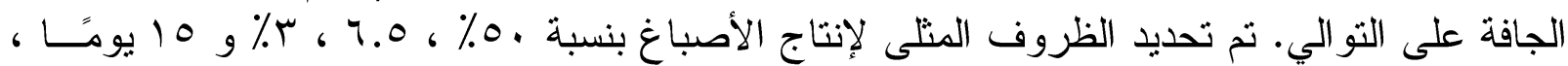

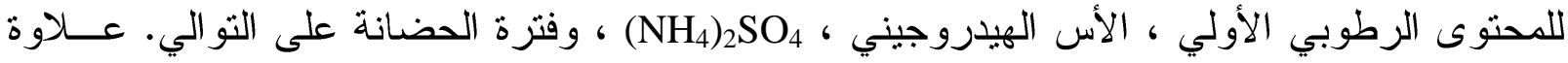

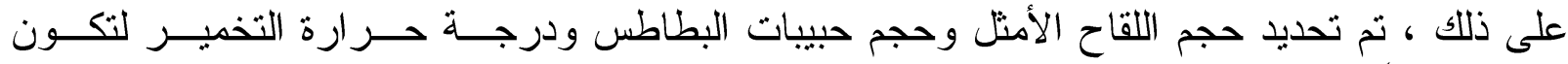

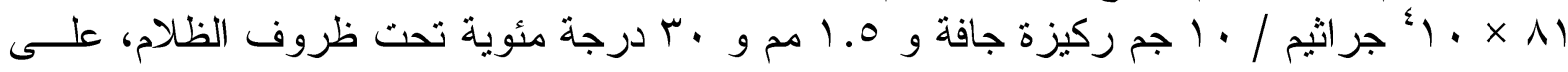

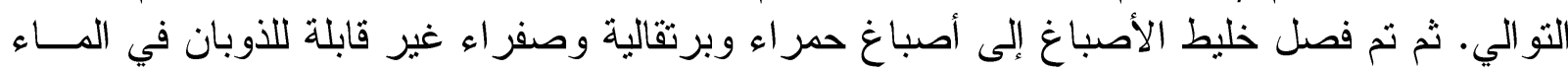

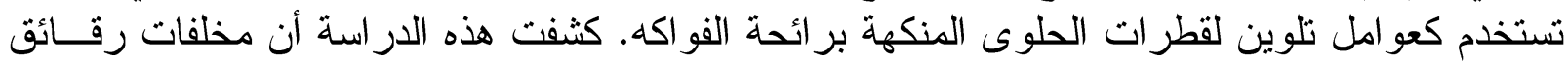
البطاطس هي مادة أولية مبتكرة لإنتاج الأصباغ بو اسطة 